\title{
The Effects of Acute Total Asphyxia and Metabolic Acidosis on Cerebrospinal Fluid Bicarbonate Regulation in Newborn Puppies
}

\author{
EUGENE E. NATTIE ${ }^{(22)}$ AND WILLIAM H. EDWARDS \\ Departments of Maternal and Child Health and Physiology, Dartmouth Medical School, Hanover, \\ New Hampshire, USA
}

\begin{abstract}
Summary
We evaluated $\mathrm{CSF}\left[\mathrm{HCO}_{3}^{-}\right]$regulation in lightly anesthetized newborn puppies following: (1) acute total asphyxia; (2) metabolic acidosis; and (3) metabolic acidosis induced after acute asphyxia. Five and one-half min of total asphyxia resulted in a $4.4 \mathrm{mM} /$ liter

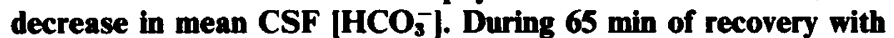
mechanical ventilation mean CSF [HCO ${ }_{3}^{-}$] increased $1.7 \mathrm{mM}$ / liter. Mean plasma $\left[\mathrm{HCO}_{3}^{-}\right]$decreased $7 \mathrm{mM} /$ liter and recovered $4.5 \mathrm{mM} /$ liter in the same period. We produced a stable metabolic acidosic for $4 \mathrm{hr}$ using a peritoneal dialysis technique with $\mathrm{PaCO}_{2}$ maintained at the normal value. With acidosis in nonasphyxiated control puppies, CSF [ $\mathrm{HCO}_{3}^{-}$] decreased steadily. At $4 \mathrm{hr}$, the

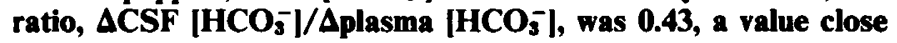
to that observed in adults of many species with metabolic acidbase disturbances, 0.41 . With acidosis in asphyxiated puppies allowed $1 \mathrm{hr}$ of recovery, the time course and mean values of plasma and $\mathrm{CSF}\left[\mathrm{HCO}_{3}^{-}\right]$were indistinguishable from those of the nonasphyxiated acidotic controls. Newborn puppies appear to regulate $\mathrm{CSF}\left[\mathrm{HCO}_{3}^{-}\right.$] in response to acute asphyxia or metabolic acidosis, and acute asphyxia does not impair the puppy's ability to regulate $\mathrm{CSF}\left[\mathrm{HCO}_{3}^{-}\right.$] in metabolic acidosis.
\end{abstract}

\section{Speculation}

The puppy can regulate $\mathrm{CSF}\left[\mathrm{HCO}_{3}^{-}\right]$in two stresses which occur commonly in the newborn period, birth asphyxia, and metabolic acidosis. This ability would help to preserve normal acidbase balance in the central nervous system during these stresses.

This study concerns cerebrospinal fluid (CSF) $\left[\mathrm{HCO}_{3}^{-}\right]$regulation in newborn puppies in three situations: (1) newborn animals have greater tolerance to asphyxia than do adults $(3,21)$. We ask whether this tolerance includes effective CSF acid-base regulation; (2) in postnatal metabolic acid-base disturbances, the newborn of some species regulate $\mathrm{CSF}\left[\mathrm{HCO}_{3}^{-}\right]$as well as adults $(8,12)$ whereas in other species, the newborn are less effective than are adults (9). Because the puppy is a commonly used model for studies of the physiology and pathophysiology of the neonatal period $(5,7,21)$, we determine how well $\mathrm{CSF}$ [ $\left.\mathrm{HCO}_{3}^{-}\right]$is regulated in the puppy with metabolic acidosis (3); hypercapnia alters the normal distribution between CSF and blood of sucrose infused in newborn sheep which is interpreted to represent a $\mathrm{CO}_{2}$-induced change in cerebral vascular permeability (2). We ask whether prior asphyxia can also alter CSF regulatory processes, in this case $\mathrm{CSF}\left[\mathrm{HCO}_{3}^{-}\right]$regulation in metabolic acidosis.

\section{METHODS}

Pregnant beagle dogs were obtained from Marshall Research Animals, North Rose, N.Y. and shipped to Hanover more than two wk before the estimated date of delivery. The dogs were fed Purina dog chow and water ad libitum. Following normal spontaneous birth, puppies were at least one hr and no more than 4 days of age at the time of experiment.

The general design included 4 groups in two basic experiments. In the first experiment, the control puppies (group 1) experienced mock acute asphyxia for $5 \frac{1}{2} \mathrm{~min}$, and the experimental puppies (group 2) experienced acute asphyxia for the same time period, a stress which beagle puppies can tolerate with $100 \%$ recovery (21). We measured blood acid-base values and CSF total $\mathrm{CO}_{2}\left(\mathrm{TCO}_{2}\right)$ in both groups over the $60 \mathrm{~min}$ following asphyxia. In the second experiment, the period of mock asphyxia (group 3) and asphyxia (group 4) was $7 \frac{1}{2} \mathrm{~min}$. One hr was allowed for recovery. Following the recovery period, both groups ( 3 and 4 ) were dialyzed by IP injection of a solution that induced metabolic acidosis via $\mathrm{Cl}^{-}$, $\mathrm{HCO}_{3}^{-}$exchange across the peritoneal membrane with no change in plasma $\left[\mathrm{Na}^{+}\right]$or osmolality. We measured blood acid-base and electrolyte values and CSF $\mathrm{TCO}_{2}$ just prior to dialysis and during $4 \mathrm{hr}$ after the onset of the dialysis.

In all cases, the puppies were anesthetized with 2 or $3 \%$ Halothane in oxygen, tracheostomized, and connected via an endotracheal tube to a small animal ventilator (Harvard Rodent Respirator model 680). The tidal volume and frequency of the ventilator were initially set at values that from past experience would maintain normal $\mathrm{PaCO}_{2}$ and $\mathrm{PaO}_{2}$. The femoral artery was catheterized, and the puppy was placed in a small animal sterotaxic device (Kopf Instruments). The atlanto-occipital membrane was exposed with careful hemostasis achieved by electrocoagulation. Body temperature was maintained at $37.5^{\circ} \mathrm{C}$ using a YSI Proportional Temperature Controller model 72. Following completion of surgery, the inspired anesthetic agent was switched to a mixture of 0 to $0.5 \%$ Halothane, $70 \%$ nitrous oxide, and oxygen. During the 30 min allowed for equilibration at these new anesthetic levels, we measured $\mathrm{PaCO}_{2}$ on blood obtained from the femoral catheter and changed ventilator settings if necessary. Blood pressure was measured with a Statham pressure transducer and recorded on a Grass Instrument Co. oscillograph.

We produced acute total asphyxia by clamping the tracheal tube and shutting off the respirator. At the end of the asphyxial period, we unclamped the trachea and turned on the ventilator providing a few initial deep breaths. In groups 1 and 2 , arterial blood was obtained as soon as possible after the end of asphyxia, usually in the 1 to 2 -min period followed by second and third samples at 20 and $60 \mathrm{~min}$ after the end of asphyxia. Blood $\mathrm{pH}$ and $\mathrm{PCO}_{2}$ were measured with Radiometer electrodes at $37.5^{\circ} \mathrm{C}$, and appropriate body temperature corrections were made as needed $(19,20)$. Plasma $\mathrm{HCO}_{3}^{-}$was calculated using the HendersonHasselbalch equation and appropriate values of $\mathrm{pK}$ and $\mathrm{S}$ (19, 20). We obtained CSF by puncture of the atlanto-occipital membrane with a micromanipulator-held tapered glass capillary tube and measured total $\mathrm{CO}_{2}$ content $\left(\mathrm{TCO}_{2}\right)$ on $30 \mu \mathrm{l}$ of sample using 
a Natelson microgasometer. The CSF was sampled at 7, 25, and $65 \mathrm{~min}$ after the end of asphyxia. At $65 \mathrm{~min}$, we obtained a second CSF sample and measured $\mathrm{pH}$. This $\mathrm{pH}$ and the $\mathrm{TCO}_{2}$ were used to calculate CSF $\mathrm{PCO}_{2}$ by the relationship, $\mathrm{pH}=\mathrm{pK}+\log$ $\left[\left(\mathrm{TCO}_{2} / \mathrm{S} \cdot \mathrm{PCO}_{2}\right)-1\right]$ with $\mathrm{pK}$ and $\mathrm{S}$ values obtained for $\mathrm{CSF}$ (14). The mean observed $\triangle \mathrm{PCO}_{2}$ (CSF - arterial) for the final CSF samples in group 1 was used to calculate all CSF $\mathrm{PCO}_{2}$ and $\mathrm{HCO}_{3}^{-}$values in group 1 using $\mathrm{PaCO}_{2}$ and the relationship CSF $\left[\mathrm{HCO}_{3}^{-}\right]=\mathrm{TCO}_{2}-\left(\mathrm{S} \cdot \mathrm{PCO}_{2}\right)$. The same procedure was followed in group 2.

In groups 3 and 4, the puppies were treated as above except that the duration of asphyxia was increased. Following one hr of recovery from asphyxia, we-took control blood and CSF samples and injected the peritoneal space with a solution warmed to body temperature consisting of: $\mathrm{NaCl}, 150 \mathrm{mM} /$ liter, $\mathrm{KCl}, 1 \mathrm{mM} /$ liter, $\mathrm{CaCl}, 1 \mathrm{mM} /$ liter, $\mathrm{MgCl}, 1 \mathrm{mM} /$ liter, glucose, $100 \mathrm{mg} \%$, and $\mathrm{HCl}, 60 \mathrm{mM} /$ liter. Subsequent blood samples were obtained for acid-base determinations at $1,2,3$, and $4 \mathrm{hr}$ and for electrolyte determinations at 1,2 , and $4 \mathrm{hr}$. CSF was sampled at 2,3 , and 4 hr. Plasma $\mathrm{Na}^{+}$and $\mathrm{K}^{+}$were measured with a flame photometer, and $\mathrm{Cl}^{-}$was measured with Radiometer CMT-10 Chloride titrator. CSF $\mathrm{TCO}_{2}$ was measured in all samples. For the predialysis control period, the mean $\Delta \mathrm{PCO}_{2}$ (CSF - arterial) from groups 1 and 2 was used to calculate $\mathrm{CSF} \mathrm{PCO}_{2}$ and $\mathrm{HCO}_{3}^{-}$for groups 3 and 4 , respectively. With the final 4-hr CSF sample, CSF pH was measuied as in groups 1 and 2 , and the mean $\triangle \mathrm{PCO}_{2}$ (CSF arteriai) observed for groups 3 and 4 was used to calculate CSF PCC and $\left[\mathrm{HCO}_{3}^{-}\right]$values at 2,3 , and $4 \mathrm{hr}$ after the onset of analysis.

We used $\mathrm{CSF} \mathrm{TCO}_{2}$ as a reliable measure of $\mathrm{CSF}\left[\mathrm{HCO}_{3}^{-}\right]$, the variable of primary interest. Whereas largely $\mathrm{HCO}_{3}^{-}, \mathrm{CSF} \mathrm{TCO}$ does include a small amount of dissolved $\mathrm{CO}_{2}$. This was calculated using the solubility of $\mathrm{CO}_{2}$ in $\mathrm{CSF}$ (14) and an estimate of CSF $\mathrm{PCO}_{2}$. We wanted to minimize the volume of CSF sampled. Therefore, small samples of CSF were taken sufficient only for measurement of $\mathrm{TCO}_{2}(30 \mu \mathrm{l})$ until the end of each experiment when a second sample was obtained for measurement of $\mathrm{pH}$ and calculation of the CSF $\mathrm{PCO}_{2}$ for that sample. The $\triangle \mathrm{PCO}_{2}$ (CSF - arterial) value calculated with this $\mathrm{CSF} \mathrm{PCO}_{2}$ was applied to other measurements. We made these final $\mathrm{pH}$ measurements rather than estimating $\mathrm{CSF} \mathrm{PCO}_{2}$ (the actual value of $\mathrm{CSF} \mathrm{PCO}_{2}$ is of little importance because the amount of dissolved $\mathrm{CO}_{2}$ is quite small) to evalute whether asphyxia with or without subsequent metabolic acidosis affected the $\triangle \mathrm{PCO}_{2}(\mathrm{CSF}$ - arterial).

\section{RESULTS}

All animals appeared to be in good health. Litter size varied from 2 to 9 puppies with body weights ranging from 270 to $400 \mathrm{~g}$.
The results from the first experiment are shown in Table 1 and Figure 1. The initial mean pretreatment blood acid-base and blood pressure values for groups 1 and 2 were quite similar. In group 1 during the post mock asphyxia recovery period, blood acid-base values were stable, and whereas mean arterial blood pressure decreased slightly, the change was not statistically significant. The CSF [ $\mathrm{HCO}_{3}^{-}$] value of $28 \mathrm{mM} /$ liter was high compared to normal adult dog values of 22 to $24 \mathrm{mM} / \mathrm{liter}(4,11)$ and was maintained through the entire period in which measurements were made.

During asphyxia (group 2), a metabolic and respiratory acidosis developed. The mean value for $\mathrm{PaCO}_{2}$ at 1 to $2 \mathrm{~min}$ after cessation of asphyxia was $59.5 \mathrm{~mm} \mathrm{Hg}$, for $\mathrm{pH}$, it was 7.03 , and for $\mathrm{HCO}_{3}^{-}$,

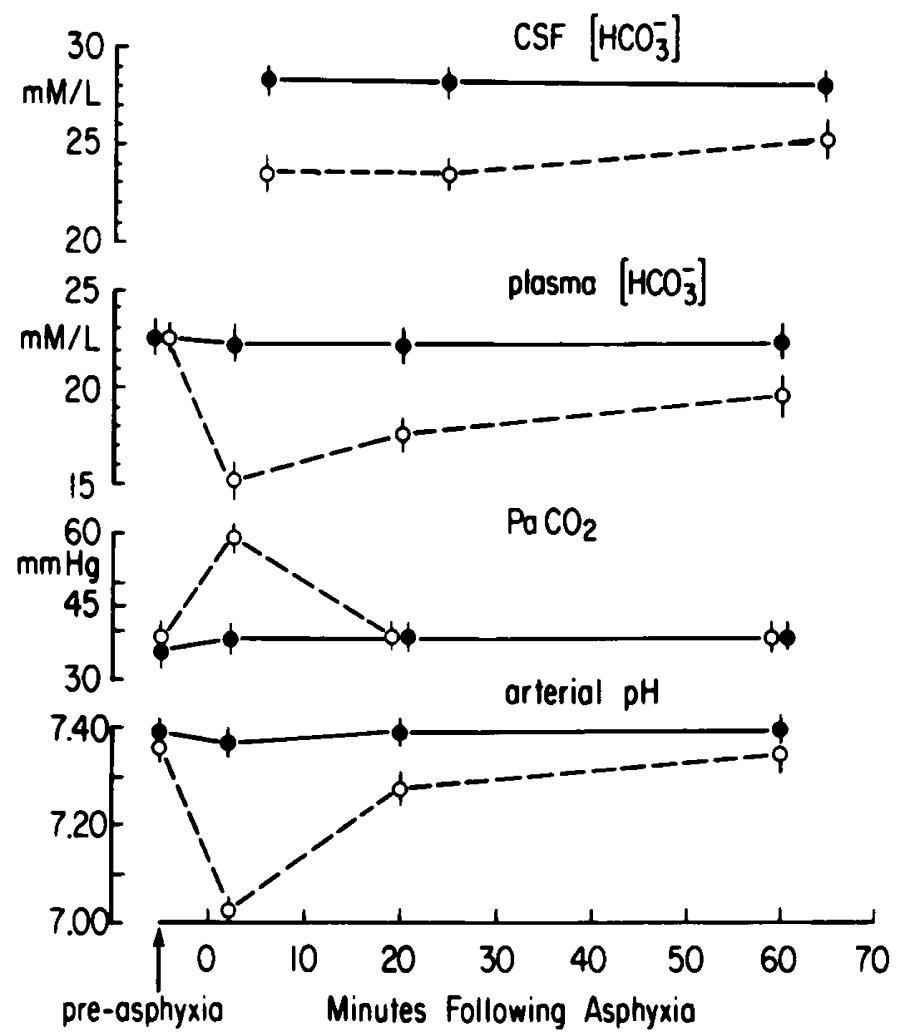

Fig. 1. Mean \pm S.E. CSF $\left[\mathrm{HCO}_{3}^{-}\right]$, plasma $\left[\mathrm{HCO}_{3}^{-}\right], \mathrm{PaCO}_{2}$, and arterial $\mathrm{pH}$ are shown as a function of time in $\mathrm{min}$ following $5.5 \mathrm{~min}$ of acute total asphyxia., group 1 control animals; $O$, group 2 asphyxiated animals. The initial values are preasphyxia control values for each group. The CSF samples were obtained slightly later than the blood samples.

Table 1. Arterial and cerebrospinal fluid acid-base values and mean arterial blood pressure before and after 5.5 min of "mock" acute total asphyxia (group 1) and asphyxia (group 2)

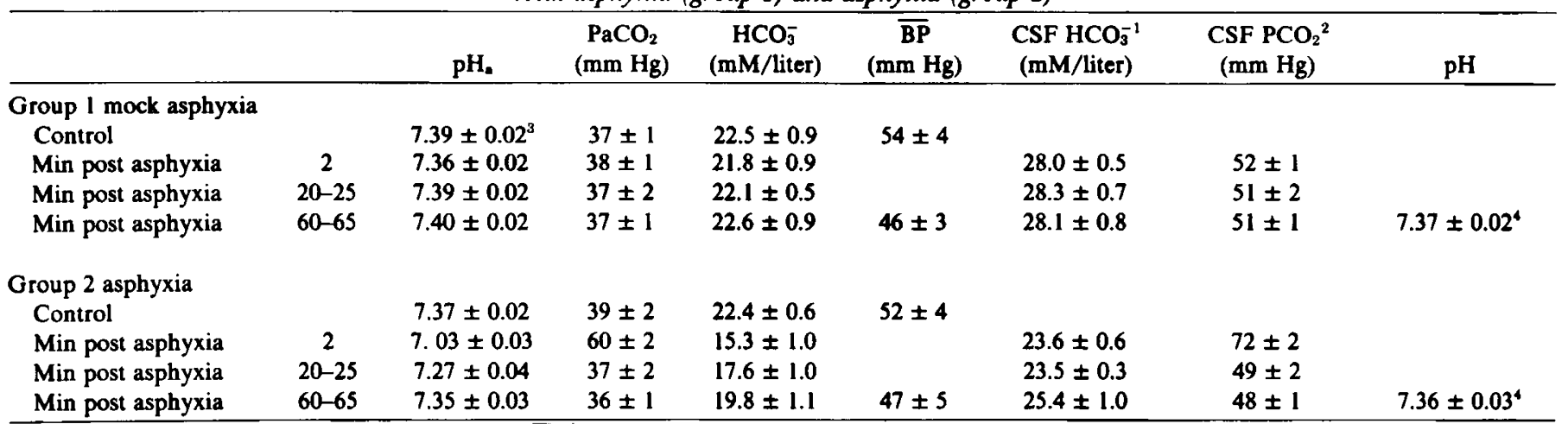

' $\mathrm{HCO}_{3}^{-}=\mathrm{TCO}_{2}-\left(\mathrm{PCO}_{2} \times \mathrm{s}\right)$, where $\mathrm{s}=$ solubility in $\mathrm{CSF}$ (see text).

${ }^{2}$ Calculated from $\mathrm{PaCO}_{2}$ using $\triangle \mathrm{PCO}_{2}$ (CSF-aiterial) measured at end of each experiment via $\mathrm{pH}$ and $\mathrm{TCO}_{2}$ data.

${ }^{3}$ Mean \pm S.E.; $N=5$ for both groups.

${ }^{4}$ Measured CSF pH. 
25

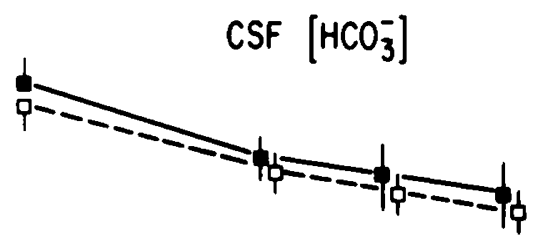

(25)

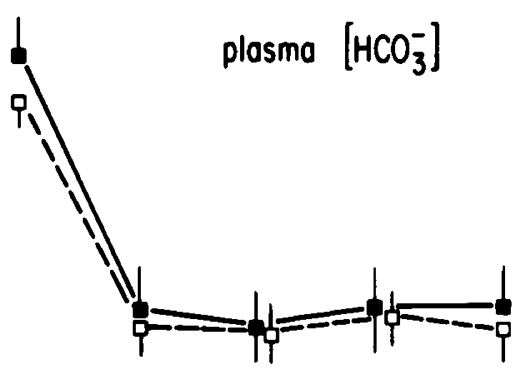

${ }^{60}$

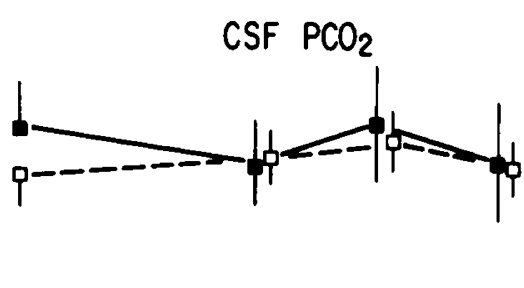

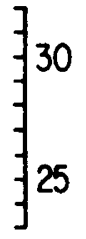
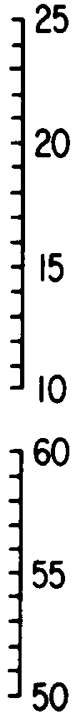

50

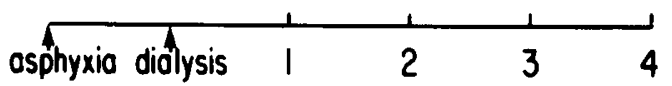

\section{Hours Following Dialysis}

Fig. 2. Mean \pm S.E. CSF $\left[\mathrm{HCO}_{3}^{-}\right]$, plasma $\left[\mathrm{HCO}_{3}^{-}\right]$and $\mathrm{CSF} \mathrm{PCO}_{2}$ are shown as a function of time in hr following onset of dialysis with acid. The dialysis was begun $1 \mathrm{hr}$ after cessation of $7.5 \mathrm{~min}$ of acute total asphyxia in the group 4 test animals $(\square)$. The group 3 controls ( $(\square)$ were not asphyxiated but did receive acid treatment. it was $15.3 \mathrm{mM} /$ liter. During recovery, $\mathrm{PaCO}_{2}$ reached normal values by $20 \mathrm{~min}$, and plasma $\mathrm{HCO}_{3}^{-}$and $\mathrm{pH}$ increased, but did not reach control values by $60 \mathrm{~min}$. Whereas the animals became hypotensive during asphyxia, by 60 to $65 \mathrm{~min}$ of recovery, the mean arterial blood pressure was not significantly different from either the preasphyxia control values or the group 1 value at 60 to $65 \mathrm{~min}$. The mean $\mathrm{CSF} \mathrm{HCO}_{3}^{-}$at $7 \mathrm{~min}$ after the end of asphyxia was $4.4 \mathrm{mM}$ /liter lower than the control values, and by $65 \mathrm{~min}$, the $\mathrm{CSF} \mathrm{HCO}_{3}^{-}$value had increased being only $2.7 \mathrm{mM}$ lower than the control value. The mean ( \pm S.E.) $\triangle \mathrm{PCO}_{2}$ (CSF - arterial) values calculated from the $\mathrm{CSF} \mathrm{TCO}_{2}$ and $\mathrm{pH}$ data obtained at the end of the experiment in groups 1 and 2 were $14 \pm 3$ and 12 $\pm 2 \mathrm{~mm} \mathrm{Hg}$, respectively. Mean CSF pH at $65 \mathrm{~min}$ was the same in both groups.

The results from the second experiment are shown in Figure 2 and Tables 2 and 3. The initial mean arterial blood pressure, mean plasma electrolyte, and blood and CSF acid-base values were not significantly different in the two groups. $\mathrm{PaCO}_{2}$ was well controlled throughout the experiment in both groups. The dialysis produced and maintained the same degree of acidosis in both groups for the duration of the experiment. Plasma $\left[\mathrm{HCO}_{3}^{-}\right]$decreased as plasma $\left[\mathrm{Cl}^{-}\right]$increased, and at any sampling time, the mean $\left[\mathrm{HCO}_{3}^{-}\right]$and $\left[\mathrm{Cl}^{-}\right]$values of each group were not significantly different. Plasma $\left[\mathrm{Na}^{+}\right]$was statistically unchanged in either group throughout the experiment. Plasma $\left[\mathrm{K}^{+}\right]$increased significantly in both groups $(P<0.01)$, but the mean values at any sample time were not different between the groups. Mean arterial blood pressure tended to decrease during the acidosis in both groups.

The mean $\triangle \mathrm{PCO}_{2}(\mathrm{CSF}$ - arterial) values at the end of the second experiment were $18 \pm 1 \mathrm{~mm} \mathrm{Hg}$ for group 3 and $16 \pm 1$ $\mathrm{mm} \mathrm{Hg}$ for group 4, values that were not significantly different. Figure 2 shows the time course of $\mathrm{CSF}\left[\mathrm{HCO}_{3}^{-}\right]$and the two variables most likely to be causally related to it, $\mathrm{CSF} \mathrm{PCO}_{2}$ and plasma $\left[\mathrm{HCO}_{3}^{-}\right](6,13,16)$. Plasma $\left[\mathrm{HCO}_{3}^{-}\right]$decreased the same amount in both groups and was quite stable over the course of the experiment. The mean $\mathrm{CSF}\left[\mathrm{HCO}_{3}^{-}\right]$values for both groups were indistinguishable at any sample time.

Table 2. Arterial and cerebrospinal fluid acid-base values and mean arterial blood pressure during metabolic acidosis induced 1 hr following 7.5 min of "mock" acute total asphyxia (group 3) and asphyxia (group 4)

\begin{tabular}{|c|c|c|c|c|c|c|c|c|}
\hline & & $\mathrm{pH}_{\mathrm{a}}$ & $\begin{array}{c}\mathrm{PaCO}_{2} \\
(\mathrm{~mm} \mathrm{Hg})\end{array}$ & $\begin{array}{c}\mathrm{HCO}_{3}^{-} \\
\text {(mM/liter) }\end{array}$ & $\begin{array}{c}\overline{\mathrm{BP}} \\
(\mathrm{mm} \mathrm{Hg})\end{array}$ & $\begin{array}{c}{\mathrm{CSF} \mathrm{HCO}_{3}^{-1}}_{\mathrm{mM} / \text { liter) }} \\
\end{array}$ & $\begin{array}{c}\mathrm{CSF} \mathrm{PCO} \\
(\mathrm{mm} \mathrm{Hg})\end{array}$ & $\mathrm{pH}$ \\
\hline \multicolumn{9}{|l|}{ Group 3 mock asphyxia } \\
\hline Control & & $7.34 \pm 0.03^{2}$ & $42 \pm 2$ & $23.4 \pm 1.5$ & $50 \pm 3$ & $29.5 \pm 1.0$ & $57 \pm 2^{3}$ & \\
\hline $\begin{array}{l}\text { Hr past onset of aci- } \\
\text { dosis }\end{array}$ & 1 & $7.19 \pm 0.03$ & $35 \pm 2$ & $13.2 \pm 1.5$ & & & & \\
\hline $\begin{array}{l}\text { Hr past onset of aci- } \\
\text { dosis }\end{array}$ & 2 & $7.13 \pm 0.03$ & $38 \pm 2$ & $12.5 \pm 1.3$ & $58 \pm 3$ & $26.6 \pm 0.7$ & $56 \pm 2^{4}$ & \\
\hline $\begin{array}{l}\mathrm{Hr} \text { past onset of aci- } \\
\text { dosis }\end{array}$ & 3 & $7.15 \pm 0.04$ & $39 \pm 2$ & $13.4 \pm 1.6$ & & $25.9 \pm 1.3$ & $57 \pm 2^{4}$ & \\
\hline $\begin{array}{l}\text { Hr past onset of aci- } \\
\text { dosis }\end{array}$ & 4 & $7.16 \pm 0.04$ & $38 \pm 2$ & $13.4 \pm 1.6$ & $39 \pm 4$ & $25.2 \pm 1.2$ & $56 \pm 2^{4}$ & $7.29 \pm 0.02^{5}$ \\
\hline \multicolumn{9}{|l|}{ Group 4 asphyxia } \\
\hline Control & & $7.34 \pm 0.02$ & $41 \pm 1$ & $21.6 \pm 0.6$ & $55 \pm 2$ & $28.2 \pm 0.6$ & $55 \pm 1^{3}$ & \\
\hline $\begin{array}{l}\text { Hr past onset of aci- } \\
\text { dosis }\end{array}$ & 1 & $7.12 \pm 0.03$ & $40 \pm 1$ & $12.5 \pm 1.0$ & & & & \\
\hline $\begin{array}{l}\text { Hr past onset of aci- } \\
\text { dosis }\end{array}$ & 2 & $7.13 \pm 0.03$ & $38 \pm 1$ & $12.3 \pm 1.1$ & $48 \pm 3$ & $26.1 \pm 0.7$ & $54 \pm 1^{4}$ & \\
\hline $\begin{array}{l}\text { Hr past onset of aci- } \\
\text { dosis }\end{array}$ & 3 & $7.15 \pm 0.03$ & $39 \pm 1$ & $13.0 \pm 0.8$ & & $24.9 \pm 0.6$ & $55 \pm 1^{4}$ & \\
\hline $\begin{array}{l}\text { Hr past onset of aci- } \\
\text { dosis }\end{array}$ & 4 & $7.13 \pm 0.04$ & $37 \pm 1$ & $12.4 \pm 1.1$ & $48 \pm 3$ & $24.4 \pm 0.5$ & $53 \pm 1^{4}$ & $7.30 \pm 0.01^{5}$ \\
\hline
\end{tabular}

${ }^{1} \mathrm{HCO}_{3}^{-}=\mathrm{TCO}_{2}-\left(\mathrm{PCO}_{2} \times \mathrm{s}\right)$, where $\mathrm{s}$ is solubility in CSF (see text).

${ }^{2}$ Mean \pm S.E.; $N=6$ in both groups.

${ }^{3} \mathrm{CSF} \mathrm{PCO}_{2}$ calculated from $\mathrm{PaCO}_{2}$ and the $\triangle \mathrm{PCO}_{2}(\mathrm{CSF}$-arterial) obtained in group 1 .

${ }^{4} \mathrm{CSF} \mathrm{PCO}_{2}$ calculated from $\mathrm{PaCO}_{2}$ and the $\triangle \mathrm{PCO}_{2}\left(\mathrm{CSF}\right.$-arterial) obtained at the end of the group $3+4$ experiments via $\mathrm{pH}$ and $\mathrm{TCO} \mathrm{O}_{2}$ data.

${ }^{5}$ Measured CSF pH. 
Table 3. Plasma electrolyte composition during peritoneal dialysis-induced metabolic acidosis following "mock" acute total asphyxia (group 3) and asphyxia (group 4)

\begin{tabular}{|c|c|c|c|c|c|c|c|c|}
\hline & \multicolumn{2}{|c|}{ Control ( $1 \mathrm{hr}$ post asphyxia) } & \multicolumn{2}{|c|}{$1 \mathrm{hr}$ post dialysis } & \multicolumn{2}{|c|}{$2 \mathrm{hr}$ post dialysis } & \multicolumn{2}{|c|}{$4 \mathrm{hr}$ post dialysis } \\
\hline & Group 3 & Group 4 & Group 3 & Group 4 & Group 3 & Group 4 & Group 3 & Group 4 \\
\hline \multirow[t]{2}{*}{ Sodium (mM/liter) } & $145^{1}$ & 141 & 147 & 142 & 146 & 141 & 148 & 142 \\
\hline & 4 & 1 & 4 & 2 & 4 & 1 & 5 & 2 \\
\hline \multirow[t]{2}{*}{ Potassium (mM/liter) } & 3.9 & 4.1 & 4.6 & 5.0 & 4.9 & 5.4 & 6.4 & 6.9 \\
\hline & 0.4 & 0.2 & 0.4 & 0.4 & 0.4 & 0.4 & 0.6 & 0.6 \\
\hline \multirow[t]{2}{*}{ Chloride (mM/liter) } & 107 & 111 & 124 & 123 & 124 & 123 & 124 & 123 \\
\hline & 1 & 5 & 3 & 2 & 2 & 2 & 1 & 2 \\
\hline
\end{tabular}

${ }^{1}$ Mean \pm S.E.; $N=4$ to 6 in each group.

The mean $\mathrm{PaO}_{2}$ values in all 4 groups at all times of measurement ranged from $98 \pm 15$ to $176 \pm 31 \mathrm{~mm} \mathrm{Hg}$.

\section{DISCUSSION}

We use halothane anesthesia (2 to $3 \%$ ) for surgery followed by inhalation of nitrous oxide-oxygen mixtures for analgesia supplemented with minimal halothane $(0.5 \%)$ as needed. We believe that done carefully, this commonly used approach $(5,21)$ has little effect on subsequent blood and CSF values. Our initial blood acid-base values measured $30 \mathrm{~min}$ after the cessation of surgical halothane anesthesia agree well with those measured in awake, unanesthetized beagle puppies (7), which argues against any significant hypotension and lactic acidosis during surgery. Our mean arterial blood pressure values also agree well with published data: $62 \pm 10(7), 53 \pm 2(5)$, and approximately $48 \mathrm{~mm} \mathrm{Hg}$ (21) obtained in experiments with anesthetic and surgical preparations like ours.

The mean $\triangle \mathrm{PCO}_{2}(\mathrm{CSF}$ - arterial) values of the two groups at the end of the first experiment are not different statistially and are similar to those reported from experiments in adult animals performed under similar conditions, anesthetized, and ventilated with positive pressure $(1,16,17)$. The mean $\triangle \mathrm{PCO}_{2}(\mathrm{CSF}-$ arterial) values are larger at the end of the second experiment but are not different between the two groups. This widening of the $\triangle \mathrm{PCO}_{2}$ value during the course of an experiment in an anesthetized animal has also been observed in adults of this and other species $(1,16,17)$. In the puppy, the widening is probably not due to a change in the ratio of cerebral blood flow to cerebral metabolic rate because this is reported to be unchanged in newborn puppies treated as in our protocol although both CBF and CMR are lower in puppies than in dogs $(5,7)$. Although the mechanisms which cause the widening $\triangle \mathrm{PCO}_{2}$ are unclear, we conclude that neither asphyxia nor asphyxia and induced metabolic acidosis result in a measured $\triangle \mathrm{PCO}_{2}$ (CSF - arterial) value that is different from the value observed in controls.

The initial mean CSF [ $\left.\mathrm{HCO}_{3}^{-}\right]$values of all groups and all of the group one $\mathrm{CSF}$ [ $\mathrm{HCO}_{3}^{-}$] values are in the range of 28 to 30 $\mathrm{mM} /$ liter. These values are greater than those reported in adult dogs, 22 to $24 \mathrm{mM} /$ liter $(4,11)$. It is difficult to explain this finding in our study on the basis of artifact. Transient, undetected, very high cerebral $\mathrm{PCO}_{2}$ values would have little effect on the $\left[\mathrm{HCO}_{3}^{-}\right]$in CSF per se because it is an essentially unbuffered fluid or on the $\mathrm{TCO}_{2}$ because the solubility of $\mathrm{CO}_{2}$ in CSF is only on the order of $0.03 \mathrm{mM} / 1 \cdot \mathrm{mm} \mathrm{Hg}^{-1}$. Although increased cerebral $\mathrm{PCO}_{2}$ in vivo does increase $\mathrm{CSF}\left[\mathrm{HCO}_{3}^{-}\right]$, the response is not immediate, and the sensitivity is on the order of $0.16 \mathrm{mM} / 1 \cdot \mathrm{mm}$ $\mathrm{Hg}^{-1}$ in adults (16). Furthermore, in group one, the high CSF $\left[\mathrm{HCO}_{3}^{-}\right]$values are stable over a period of $1 \mathrm{hr}$ after the surgical preparation, and in group 2, under controlled conditions following asphyxia, the $\mathrm{CSF}\left[\mathrm{HCO}_{3}^{-}\right.$] values recover quickly and approach the control level. These facts do not support any irreversible effect of anesthesia and surgery which might result in a high CSF $\left[\mathrm{HCO}_{3}^{-}\right]$value. A comparison with other species shows that in newborn lambs and humans, the $\mathrm{CSF}\left[\mathrm{HCO}_{3}^{-}\right]$values are close to those in adults $(8,12)$ whereas in rats, the newborn values are higher than in adults (9). We conclude that the newborn puppy like the rat has a $\mathrm{CSF}\left[\mathrm{HCO}_{3}^{-}\right]$higher than the adult. The significance of this high CSF $\left[\mathrm{HCO}_{3}^{-}\right]$is not understood.

The blood pressure, heart rate, and blood acid-base response of our newborn puppies to $51 / 2$ of acute asphyxia are similar to those previously described (21). With recovery (Fig. 1), $\mathrm{PaCO}_{2}$ is quickly corrected by the ventilator and plasma $\left[\mathrm{HCO}_{3}^{-}\right]$values, while still decreased at 60 to $65 \mathrm{~min}$, are close to the control values. This rapid recovery of blood acid-base balance presumably includes extra and intracellular fluid buffers and the metabolism of lactate and other organic acids produced during asphyxia. One of our main objectives is to evaluate CNS acid-base regulation in acute asphyxia. The results show a $4.5 \mathrm{mM} /$ liter decrease in $\mathrm{CSF}$ $\left[\mathrm{HCO}_{3}^{-}\right]$measured in the first minutes after asphyxia which must reflect in large part the degree of CNS metabolic acidosis. With recovery (Fig. 1), $\mathrm{CSF}\left[\mathrm{HCO}_{3}^{-}\right]$and $\mathrm{pH}$ return close to the control value by $65 \mathrm{~min}$. The source for the $\mathrm{CSF}\left[\mathrm{HCO}_{3}^{-}\right]$recovery coulc be intracellular buffers, the increased formation of CSF [ $\mathrm{HCO}_{3}^{-}$] at choroid plexus or the blood-brain barrier or the removal of the organic acid. The time course and the relative importance of these mechanisms is unknown. In adult dogs, the clearance half-time of lactate injected into the CSF is $30 \mathrm{~min}$ (18), a time roughly in keeping with that of $\mathrm{CSF}\left[\mathrm{HCO}_{3}^{-}\right]$recovery in Fig. 1. Our findings show that the acutely asphyxiated newborn puppy quickly develops a significant CNS metabolic acidosis as evidenced by the decrease in $\mathrm{CSF}$ [ $\mathrm{HCO}_{3}^{-}$] but recovers rapidly. There are few like studies in adults for comparison. In anesthetized, paralyzed, ventilated rats with $3 \mathrm{~min}$ of total asphyxia, $\mathrm{CSF}\left[\mathrm{HCO}_{3}^{-}\right]$is decreased less than $1 \mathrm{mM} /$ liter whereas tissue $\left[\mathrm{HCO}_{3}^{-}\right]$is decreased 3 to 4 $\mathrm{mM} /$ liter (10). Recovery is essentially complete by $60 \mathrm{~min}(10)$. With 5 min of total asphyxia in rats treated exactly as the puppies in this report, CSF $\left[\mathrm{HCO}_{3}^{-}\right]$is decreased only $1.4 \mathrm{mM} /$ liter, but few animals survive (15). Although far from ideal, this limited comparison suggests that the greater asphyxial tolerance of the newborn puppy is not due to a vastly superior ability to regulate CSF acid-base balance.

Adult animals regulate $\mathrm{CSF}\left[\mathrm{HCO}_{3}^{-}\right]$in response to metabolic acid-base disturbances. The ratio, $\Delta \mathrm{CSF}\left[\mathrm{HCO}_{3}^{-}\right] / \Delta$ plasma $\left[\mathrm{HCO}_{3}^{-}\right]$, in metabolic acidosis with or without partial respiratory compensation is $0.41(4,17)$. In group 3 , normal puppies stressed with a metabolic acidosis induced while $\mathrm{PaCO}_{2}$ is maintained at constant control values show a $\Delta \mathrm{CSF}\left[\mathrm{HCO}_{3}^{-}\right] / \Delta$ plasma $\left[\mathrm{HCO}_{3}^{-}\right]$value of 0.43 at $4 \mathrm{hr}$. These results indicate that the newborn puppies regulate $\mathrm{CSF}\left[\mathrm{HCO}_{3}^{-}\right]$as well as adults in response to metabolic acidosis. The mechanism of this CSF $\left[\mathrm{HCO}_{3}^{-}\right]$regulation is not fully understood in either case but probably includes an active or passive process at the blood-brain barrier which governs ionic movement between blood and brain $(6,13,16,17)$ as well as choroid plexus and brain tissue mechanisms that can respond to changes in $\mathrm{PCO}_{2}(6,13,16)$ and other stimuli.

The finding that hypercapnia can increase the CSF to plasma distribution of infused labeled sucrose in fetal and newborn lambs 
(2) raises the possibility that with asphyxia the blood-brain barrier mechanisms that in part regulate $\mathrm{CSF}\left[\mathrm{HCO}_{3}^{-}\right]$in acid-base stress may be affected. To test this, the group 4 animals were asphyxiated and then subjected to metabolic acidosis at constant $\mathbf{P C O}_{2}$. If blood-brain barrier function is altered, we would expect to observe a greater decrease in $\mathrm{CSF}\left[\mathrm{HCO}_{3}^{-}\right]$in the asphyxiated puppies than in the nonasphyxiated controls both stressed with the same decrease in plasma $\left[\mathrm{HCO}_{3}^{-}\right]$. In fact, the virtually identical decrease in $\mathrm{CSF}\left[\mathrm{HCO}_{3}^{-}\right]$in the two groups refutes this hypothesis. The $\mathrm{CSF}\left[\mathrm{HCO}_{3}^{-}\right]$regulating mechanisms appear to be unaffected by acute total asphyxia of seven and one-half-min duration.

In summary, we evaluated $\mathrm{CSF}$ [ $\left.\mathrm{HCO}_{3}^{-}\right]$regulation in newborn puppies in three conditions. Following $51 / 2 \mathrm{~min}$ of acute asphyxia, $\mathrm{CSF}\left[\mathrm{HCO}_{3}^{-}\right]$is decreased significantly, but $40 \%$ recovery occurs in $60 \mathrm{~min}$. Normal puppies appear to regulate $\mathrm{CSF}\left[\mathrm{HCO}_{3}^{-}\right]$in metabolic acidosis as well as adults of many species. And, 71/2 min of acute asphyxia does not hinder the ability of the puppy to regulate $\mathrm{CSF}\left[\mathrm{HCO}_{3}^{-}\right]$in metabolic acidosis. $\mathrm{CSF}\left[\mathrm{HCO}_{3}^{-}\right]$regulation in the puppy in these conditions appears to be quite good.

\section{REFERENCES AND NOTES}

1. Berkenbosch, A.: CSF-arterial $\mathbf{P C O}_{2}$ differences with and without ventriculocisternal perfusion in the anesthetized cat. Pfluegers Arch. Eur. J. Physiol., 330: 99 (1971).

2. Evans, C. A. N., Reynolds, J. M., Reynolds, M. L., and Saunders, M. R.: The effect of hypercapnia on a blood-brain barrier mechanism in foetal and newborn sheep. J. Physiol. (Lond.), 255: 701 (1976).

3. Fazekas, J. F., Alexander, A. D., and Himwich, H. E.: Tolerance of the newborn to anoxia. Am. J. Physiol., 134: 281 (1940).

4. Fencl, V.: Distribution of $\mathrm{H}^{+}$and $\mathrm{HCO}_{3}^{-}$in cerebral fluids. In: B. K. Siesjö, S. C. Sorensen: Ion Homeostasis of the Brain. (Academic Press, Inc., New York, 1971).

5. Gregoire, N. M., Gjedde, A., Plum, F., and Duffy, T. E.: Cerebral blood flow and cerebral metabolic rates for oxygen, glucose, and ketone bodies in newborn dogs. J. Neurochem., 30: 63 (1978).
6. Hasan, F. M., and Kazemi, H.: Dual contribution theory of regulation of CSF $\mathrm{HCO}_{3}^{-}$in respiratory acidosis. Respir. Physiol., 26: 265 (1976).

7. Hernández, M. J., Brennan, R. W., Vannucci, R. C., and Bowman, G. S.: Cerebral blood flow and oxygen consumption in the newborn dog. Am. J. Physiol., 234: R209 (1978).

8. Hodson, W. A., Fenner, A., Brumley, G., Chernick, V., and Avery, M. E.: Cerebrospinal fluid and blood acid-base relationships in fetal and neonatal lambs and pregnant ewes. Respir. Physiol., 4: 322 (1968).

9. Johanson, C. E., Woodbury, D. M., and Withrow, C. D.: Distribution of bicarbonate between blood and cerebrospinal fluid in the neonatal rat in metabolic acidosis and alkalosis. Life Sci., 19: 691 (1976).

10. Kaasik, A. E., Nilsson, L., and Siesjö, B. K.: The effect of asphyxia upon the lactate, pyruvate, and bicarbonate concentrations of brain tissue and cisternal CSF, upon the tissue concentrations of phosphocreatine and adenine nucleotides in anesthetized rats. Acta Physiol Scand., 78: 433 (1970).

11. Katzman, R., and Pappius, H. M.: Brain Electrolytes and Fluid Metabolism. p. 227 (Williams \& Wilkins Co., Baltimore, 1973).

12. Krauss, A. N., Thibeault, D. W., and Auld, P. A. M.: Acid-base balance in cerebrospinal fluid of newborn infants. Biol. Neonate, 21: 25 (1972).

13. Leusen, I.: Regulation of cerebrospinal fluid composition with reference to breathing. Physiol. Rev., 52: 1 (1972).

14. Mitchell, R. A., Herbert, D. A., and Carman, C. T.: Acid-base constants and temperature coefficients for cerebrospinal fluid. J. Appl. Physiol., 20: 27 (1965).

15. Nattie, E. E.: (umpublished data).

16. Nattie, E. E., and Romer, L.: CSF $\mathrm{HCO}_{5}^{-}$regulation in isosmotic conditions: the role of brain $\mathrm{PCO}_{2}$ and plasma $\mathrm{HCO}_{3}^{-}$. Respir. Physiol., 33: 177 (1978).

17. Pavlin, E., and Hornbein, T.: Distribution of $\mathrm{H}^{+}$and $\mathrm{HCO}_{3}^{-}$between CSF and blood during metabolic acidosis in dogs. Am. J. Physiol., 228: 1134 (1975).

18. Prockop, L. D.: Cerebrospinal fluid lactic acid. Neurology, 18: 189 (1968).

19. Severinghaus, J. W., Stupfel, M., and Bradley, A. F.: Accuracy of blood pH and $\mathrm{PCO}_{2}$ determinations. J. Appl. Physiol., 9: 189 (1956).

20. Severinghaus, J. W., Stupfel, M., and Bradley, A. F.: Variations of serum carbonic acid $\mathrm{pK}^{\prime}$ with pH and temperature. J. Appl. Physiol., 9: 197 (1956).

21. Vannucci, R. C., and Duffy, T. E.: Cerebral metabolism in newborn dogs during reversible asphyxia. Ann. Neurol., 1: 528 (1977).

22. Requests for reprints should be addressed to: Eugene E. Nattic, M.D., Department of Physiology, Dartmouth Medical School, Hanover, N. H. 03755 (USA).

23. This research was supported by grant HL 18351 from the NHLBI of NIH; Dr. Nattie is the recipient of RCDA HL 00364 from NIH.

24. Received for publication January 10, 1979.

25. Accepted for publication July 27, 1979. 